REVIEW ARTICLE

\title{
Cyclical Changes in Ovarian Angiogenesis and Its Controls
}

\author{
Sonal Panchal ${ }^{1}$, Chaitanya Nagori ${ }^{2}$
}

\begin{abstract}
The ovary is supplied by the ovarian artery and the ovarian branch of the uterine artery. Ovarian endocrinological function and ovulation is dependent on the establishment and continual remodeling of a complex vascular system. In the ovary, the development of new capillaries from preexisting ones (angiogenesis) is a complex event regulated by several hormones and angiogenic factors and also cellular changes. Expression of hormones and angiogenic factors varies throughout the cycle. Understanding of these factors and the control mechanism is essential to understand and correct abnormalities of ovulation and improve the treatment outcome of ovulation induction, in patients with subfertility.

Keywords: Cyclical vascular changes in ovary, Ovarian angiogenesis, Ovarian vascularity.

Donald School Journal of Ultrasound in Obstetrics and Gynecology (2020): 10.5005/jp-journals-10009-1635
\end{abstract}

\section{INTRODUCTION}

The ovary is supplied by the ovarian artery and the ovarian branch of the uterine artery. Small branches of the ovarian artery form a plexus in the stroma. These vessels continue toward the periphery of the follicle and subdivide into even smaller branches to make a vascular basket, that is defined as perifollicular flow (Fig. 1). As these vessels enter the cortex, these spiralize. ${ }^{1,2}$ Ovarian function is dependent on the establishment and continual remodeling of this complex vascular system. In the ovary, the development of new capillaries from preexisting ones (angiogenesis) is regulated by numerous local factors. The dominant regulators of angiogenesis in ovarian follicles and corpora lutea are the vascular endothelial growth factor (VEGF), fibroblast growth factor (FGF), insulin-like growth factor (IGF), angiopoietin (ANPT), and hypoxia-inducible factor (HIF) family members. ${ }^{3}$ Cells can send signals to activate their own receptors (autocrine), to target a neighboring cell (paracrine), or to target a distant cell (endocrine) to activate silent endothelial cells and initiate angiogenesis via proliferation, migration, and formation of new vessels. The most common means of cell communication is through soluble factors, where a signaling cell secretes a protein into the extracellular space to target a neighboring cell or travels through the bloodstream to target a cell at a distant site. The soluble factors
1,2Dr Nagori's Institute for Infertility and IVF, Jodhpur, Ahmedabad, Gujarat, India

Corresponding Author: Sonal Panchal, Dr Nagori's Institute for Infertility and IVF, Jodhpur, Ahmedabad, Gujarat, India, Phone: +91 9824050911, e-mail: sonalyogesh@yahoo.com

How to cite this article: Panchal S, Nagori C. Cyclical Changes in Ovarian Angiogenesis and Its Controls. Donald School J Ultrasound Obstet Gynecol 2020;14(2):117-124.

Source of support: Nil

Conflict of interest: None

usually bind to a tyrosine kinase receptor and trigger an intracellular response but they can also activate ion channels. There also exist different means of cell communication that can occur through soluble factors, adhesion contacts, cell junctions, or through vesicles. ${ }^{4,5}$ These are the basis of ovarian function and regulation of menstrual cycle.

In the ovary, the vascularity typically increases and decreases cyclically and is controlled by endothelial cell-specific factors and are ultimately controlled by endocrine, paracrine, and autocrine

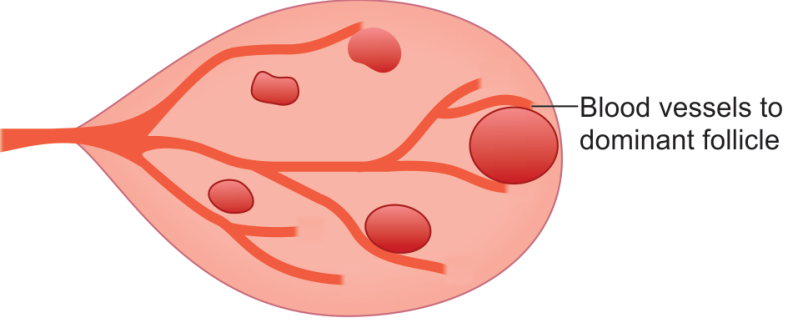

\section{A} Figs $1 \mathrm{~A}$ and B: (A) Diagrammatic demonstration of the development of the vessels around dominant follicle; (B) Color Doppler image of the
ovary showing small branches of main ovarian artery (yellow arrow) continue toward the periphery of the follicle to make a vascular basketperifollicular flow (white arrow)

() The Author(s). 2020 Open Access This article is distributed under the terms of the Creative Commons Attribution 4.0 International License (https://creativecommons. org/licenses/by-nc/4.0/), which permits unrestricted use, distribution, and non-commercial reproduction in any medium, provided you give appropriate credit to the original author(s) and the source, provide a link to the Creative Commons license, and indicate if changes were made. The Creative Commons Public Domain Dedication waiver (http://creativecommons.org/publicdomain/zero/1.0/) applies to the data made available in this article, unless otherwise stated. 
regulation and metabolic cellular signals like hypoxia and aging. ${ }^{6}$ Aberrant production of these angiogenic factors may be the cause of vascular dysfunction and the development of ovarian disorders. The study of ovarian blood vessels and angiogenic factors can help in diagnosis of ovarian disorders.

\section{Follicular Angiogenesis}

The knowledge of follicular angiogenesis is of fundamental importance not only to understand the mechanisms that ensure the reproductive success but also in order to clarify the angiogenic process in adult tissues. Ovarian angiogenesis is essential for the supply of essential nutrients and hormones to the ovary, which are vital to follicular growth and health of the corpus luteum. Angiogenesis-related mechanisms are fundamental in addressing the follicle fate through the reorganization of follicular blood vessel architecture. $^{7-9}$ Switch-on and switch-off of angiogenic pathways may be responsible for shifting the follicles from the resting phase to the active phase or vice versa. ${ }^{10}$ It has been demonstrated that circulating endothelial precursor cells, originated from the bone marrow, may contribute to angiogenesis in adults. ${ }^{11}$ Angiogenesis is characterized by a cascade of events that starts with capillary proliferation and culminates with the formation of a new microcirculation composed of arterioles, capillaries, and venules. ${ }^{12}$

\section{Vascular Network around the Follicle}

Early proliferative follicles have only thecal vascular network and are in quiescence.

Blood supply to the primordial and primary follicles for follicle growth is by passive diffusion from the stromal blood vessels. This is probably the reason why in spite of having no blood vessels, VEGF, VEGFR1 (vascular endothelial growth factor receptor 1), and VEGFR2 immunopositivity (in pregranulosa/granulosa cells) is seen in primordial and primary follicles. It is this stromal flow that decides the ovarian response and therefore is an important parameter when deciding the doses of gonadotrophins for ovulation induction. ${ }^{13,14}$ Ovarian stromal flow in the early follicular phase is related to subsequent ovarian response in IVF treatment. ${ }^{13}$ Ovarian stromal peak systolic velocity (PSV) after pituitary suppression is predictive of ovarian responsiveness and outcome of IVF treatment (Table 1). ${ }^{14}$

Though some tiny vessels may be seen close to some follicles and this is the start point for development of follicle's own vasculature $^{15,16}$ (Fig. 2). Vessels first appear as spots but then spread out on the periphery of the follicle. The blood supply increases as the follicle grows. Vascular endothelial growth factor signaling plays an important role in maintenance/activation of primordial follicles too. ${ }^{17}$ Individual vessels for a particular follicle develop in the theca layer of the secondary-stage follicle. These vessels form sort of a sheath in the theca layer of the follicle and are limited by membrana propria. ${ }^{18}$ The fibroblast growth factor 2 (FGF2) and the platelet-derived growth factor (PDGF) are present in low levels in theca interna of the antral follicles and granulosa cells. The vascularity reaches maximum in the late preantral/antral stage. The VEGF within preantral follicles seems to be dependent on the oocyte that is able to express and synthesize the angiogenic factor.

Endothelial cell proliferation is maintained in the tertiary follicles to support ongoing expansion of thecal vasculature. In the preantral stage, the vasculature is seen as double concentric network: a ring of blood vessels near to the basal membrane and spots of vessel at their periphery. The two networks are connected by anastomotic vessels. The inner layers of blood vessels on the basal membrane are smaller in diameter than the outer ones
Table 1: Ovarian stromal resistance index and peak systolic velocity (PSV) values indicating poor, normal, and hyperresponse to ovarian stimulation protocols

\begin{tabular}{llll}
\hline Baseline scan & Poor response & $\begin{array}{l}\text { Normal } \\
\text { response }\end{array}$ & Hyperresponse \\
\hline Stromal RI & $>0.7$ & $0.6-0.7$ & $<0.58$ \\
Stromal PSV & $<5 \mathrm{~cm} /$ second & $\begin{array}{l}5-10 \mathrm{~cm} / \\
\text { second }\end{array}$ & $>10 \mathrm{~cm} / \mathrm{second}$ \\
& & & \\
\hline
\end{tabular}

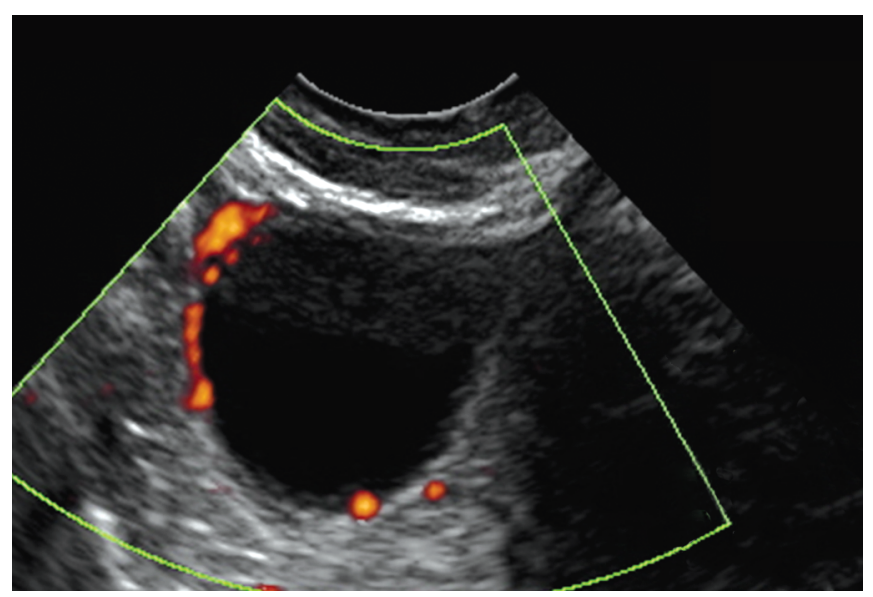

Fig. 2: Power Doppler image of a dominant follicle showing few small vessels surrounding

in the theca layer. This binary vascular network continues in early follicles and ultimately only when the follicular antrum is completely formed the follicle is both morphologically and physiologically mature. ${ }^{19}$

During dominant follicle selection, estrogen active follicles have greater vascularization and VEGFA concentrations, despite the estrogen-inactive follicle being larger in diameter. ${ }^{19}$

Dominance of the follicle can be identified by the vascularity. As the follicle grows, there is not only increase in the vascularity but there is also remodeling of the vascular tree. This is a physiological response of the dynamic development of the follicles. ${ }^{8,9,20,21}$ Perifollicular blood flow can be seen soon after the dominance of the follicle becomes evident on ultrasound, that is, from day 5-7 of the cycle. Increase in perifollicular vascularity of the dominant follicle in the theca layer starts developing as early as 8th day of the cycle. Most follicles of $10 \mathrm{~mm}$ will show perifollicular flow. A few days before ovulation, the RI of these vessels is $0.54 \pm 0.04 .^{22}$

The receptors to the angiogenic factors are found in the ovarian vascular endothelium but the angiogenesis is confined to the thecal layer. The receptors are predominantly for proangiogenic factors and the most common ones are of the VEGF family. ${ }^{9}$ VEGF 165 is the most prominent in the ovary among other factors, VEGF-B, C, and $D$, along with the placental growth factor. ${ }^{23}$

As follicles approach ovulation, the vascular expansion process is replaced by vascular maturation. Angiogenesis in the late proliferative phase in the ovaries is nonsprouting angiogenesis. In the vicinity of the inner layer, close to the lamina basalis, in a preovulatory follicle, small vessels develop and the outer thecal layer contains large vessels. ${ }^{20}$

Follicle stimulating hormone (FSH) leads to follicular growth and activates ovarian VEGF production. Its effect varies depending on the follicular diameter and the growth status. Angiogenesis and 
steroidogenesis progress parallelly and follicular morphological and physiological maturity also progress parallelly.

It is likely that the degree of luteal vascularization is, at least in part, programmed within the preovulatory follicle. The follicular vascular bed provides the basis on which the luteal vasculature is formed (Fig. 3). This then creates directionality for endothelial cell migration. It has also been believed that luteal steroidogenic cells stimulate endothelial cell migration toward themselves by producing chemoattractants.

There is also an accumulation of proangiogenic growth factors (e.g., VEGFA and FGF2) during the later stages of preovulatory follicle development. ${ }^{24}$ To a less extent, FGF2 and VEGFA have also been localized in perivascular cells, suggesting the complexity of this process rather than simple migration of angiogenic cells toward steroidogenic cells. Different isoforms of VEGFA and/or FGF2 (e.g., those that are cell-associated) are expressed in these perivascular cells. $^{25}$

Alternatively, there could be other migratory stimuli. Platelets are more potent stimulants of endothelial cell migration than granulosa cells. ${ }^{24,26}$ It is believed that though the clot is created on the ovarian surface, it could still create an environment that supports migration. The endothelial cell clusters appear to migrate toward each other rather than to steroidogenic cells in the luteal angiogenic culture system that incorporates all cell types. ${ }^{27}$ This indicates that endothelial cells themselves (and not the steroidogenic cells) produce the chemotactic factors, which then drive their migration and proliferation.

\section{Corpus Luteum Formation and Vascularity}

Metamorphosis transforms the periovulatory follicle into the corpus luteum. The follicular morphology loses the typical roundish aspect acquiring an undulated one. ${ }^{22,28}$ This seems mainly the consequence of the inner vascular plexus infolding toward the antrum. This vascular plexus is made by arterioles or venules, as from the middle network near to the basal membrane.

The vascularization of the $C L$ has one of the highest blood flows per unit tissue mass (Fig. 4). Luteal blood flow remains at preovulation levels in the collapsed follicle, but thereafter gradually increases with increasing luteal volume and coincides with rise in progesterone (Table 2). ${ }^{29}$

\section{Molecular Regulation of Follicular Angiogenesis}

The highest expression for VEGF-A, FGF-2, insulin-like growth factor 1 (IGF-1), IGF-2, angiopoietin 2 (ANPT-2)/ANPT-1, and hypoxia-induced factor (HIF)-1-alpha were found during final follicle maturation and in $\mathrm{CL}$ during the early luteal phase (days 1-4) followed by a lower plateau afterward. A single transcript of $0.8 \mathrm{~kb}$ for RAMP2 is also seen in the follicle and the corpus luteum, the level of RAMP2 mRNA is relatively high in the preovulatory follicle, while RAMP2 is present in the corpus luteum. ${ }^{30}$

\section{VEGF and Follicular Angiogenesis}

The VEGF is thought to play a paramount role in the regulation of normal and abnormal angiogenesis in the ovary. Expression of VEGF in ovarian follicles depends on follicular size. ${ }^{18}$ Biological effects of VEGF are regulated by two membrane receptors, VEGFR1 (formerly known as Flt-1) and VEGFR2 (KDR), and two soluble receptors, sVEGFR1 and sVEGFR2, which play an antagonistic role.

It is very interesting to know that the granulosa cells of the primordial and primary follicles are VEGF-negative, that of preantral follicles are weakly positive on immunostaining assessment and remain weakly positive for the entire follicular phase. Immunostaining for VEGF in the theca interna is well correlated with proliferative cell nuclear antigen (PCNA) positivity. ${ }^{17}$

The antral follicle development is dependent on angiogenesis by the way of permeabilizing activity of VEGF and is thought to be involved in follicle antrum formation. ${ }^{18}$ In the normal ovary, VEGF action may involve disruption of endothelial cell tight junction protein complex formation leading to endothelial cell fenestrations. $^{31}$

The VEGF has potent permeability actions and may act as a survival factor for immature vessels. The vessels cannot cross the basal membrane barrier; therefore, the granulosa cells create a gradient that maintains the presence of blood vessels close to the basal membrane. This is essential for the sustenance of the ovum. Therefore, in spite of being avascular, the granulosa cells have an expression of VEGF. ${ }^{31}$

Endocrine gland VEGF (EG-VEGF) produced from the ovary is also considered as a regulator of ovarian angiogenesis. ${ }^{32}$ Endocrine gland VEGF consists of 86 amino acids. ${ }^{33}$ It acts by G-proteincoupled receptors, prokineticin-R1, and prokineticin-R2. ${ }^{34,35}$ This is a promising angiogenic factor and has a specific action on steroidogenic tissues. ${ }^{33}$ Endocrine gland VEGF and VEGF also cooperate to promote angiogenesis in the corpus luteum. ${ }^{32}$ Endocrine gland VEGF is a human endothelial cell mitogen and primarily promotes the growth of adrenal cortex endothelial cells. It selectively promotes proliferation, survival, and chemotaxis of endothelial cells isolated from steroidogenic tissues. ${ }^{36}$ It is strongly
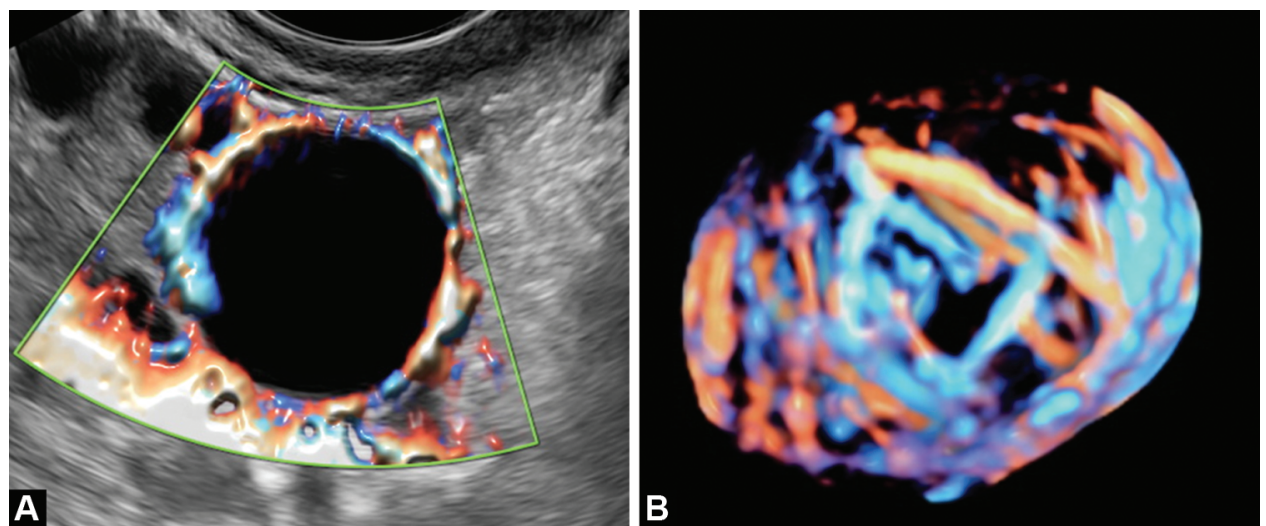

Figs 3A and B: (A) Mature follicle showing perifollicular flow on HD power Doppler; (B) Mature follicle showing perifollicular flow on 3D power Doppler (HD flow) 

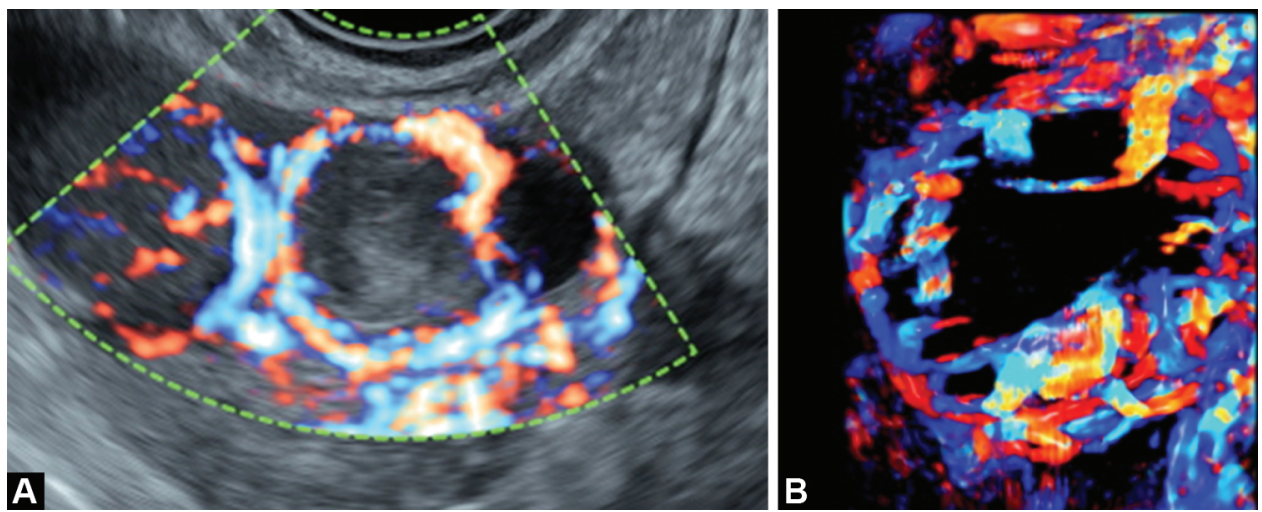

Figs 4A and B: (A) Pericorpus luteal blood flow as seen on HD power Doppler flow; (B) Pericorpus luteal blood flow as seen on 3D power Doppler (HD flow)

Table 2: Vascular parameters of the follicle during the menstrual cycle

\begin{tabular}{lll}
\hline Ovarian flow & Resistance index & Peak systolic velocity \\
\hline Preovulatory flow & $<0.48$ & $>10 \mathrm{~cm} /$ second \\
Early luteal & $0.48-0.55$ & $5-10 \mathrm{~cm} / \mathrm{second}$ \\
Mid-luteal & $<0.5$ & $>10 \mathrm{~cm} /$ second \\
Late luteal & $>0.55$ & $<6 \mathrm{~cm} /$ second \\
\hline
\end{tabular}

expressed in granulosa cells of primordial and primary follicles but its expression declines as the follicle matures. ${ }^{37}$ At approximately 5 days' postovulation, both VEGF-A and EG-VEGF are strongly expressed in a portion of granulosa lutein cells, whereas at 8 days' postovulation EG-VEGF expression is intense in the theca lutein cells, while VEGF expression has diminished to the point where only weak signal remains in the peripheral thecal cells. ${ }^{38}$ Endocrine gland VEGF is also produced from adrenal glands, testis in males, and in small amount from small intestines to control intestinal peristalsis. Ovarian EG-VEGF has a similar function as VEGF, viz., endothelial cell proliferation, migration, and fenestration, but is limited to endocrine glands. ${ }^{18}$ Endocrine gland VEGF mRNA increases as the corpus luteum matures.

\section{Early Follicular Growth and the Angiogenic Factors}

Increase in VEGF mRNA expression is observed within the granulosa cells in the late secondary and tertiary stages of follicles, while its expression in the theca is lower and remains fairly constant during the early follicular phase. This is the stage of follicular development that progresses toward the gonadotropin-dependent stage and VEGF mRNA is stimulated by gonadotropins. Angiopoietin 1 and 2 are also required for the VEGF-initiated vasculature to mature. Angiopoietin 1 and 2 act through the tyrosine kinase receptor, Tie 2. ${ }^{39}$ Specifically, Ang-1 activation of Tie-2 enhances the maturation and stability of newly formed blood vessels. Ang-2 also binds to Tie-2, but acts as an endogenous antagonist, blocking Ang-1-mediated receptor phosphorylation. In the presence of VEGF, increased autocrine expression of Ang- 2 by the vascular endothelium is associated with angiogenesis, while in the absence of VEGF or other proangiogenic factors, its expression is associated with degenerative changes in the vasculature. The Ang-1:Ang-2 ratio in follicles is associated with development and atresia. ${ }^{39}$

It is still not clear as to what initiates and promotes vascular proliferation through VEGF-A expression in the preantral and antral follicles because hypoxia induced factor (HIF) $1 \propto$ is not present in preantral follicles. Hypoxia induced factor $1 \propto$ is a potent inducer of VEGF-A otherwise. ${ }^{40}$ Though it is understood that it is imbalance of the pro- and anti-apoptotic protein that leads to increase in ovarian apoptosis and follicular atresia. ${ }^{41}$ Thrombospondins suppress the blood vessel development in the early stages, thus restricting the follicle growth till the synchronized series of events for follicle maturation set into action. Primordial and preantral follicles have PDGF and FGF2. These are derived from oocytes, and may be responsible for vascularity of these follicles. ${ }^{42-44}$

Among other factors responsible for angiogenesis are estrogens, by directly acting on endothelial cells or by inducing angiogenic factors. ${ }^{45}$

\section{Preovulatory Phase and Angiogenic Factors}

The follicular environment during this preovulatory phase must be supported by high oxygen tension, where gases must diffuse from the vessels present in theca layers through the basal membrane to reach the granulosa layer and the oocyte. ${ }^{44}$ The VEGFA has been shown to upregulate endothelial nitric oxide synthase (eNOS) expression ${ }^{46}$ while nitric oxide increases the expression of FGF2 and VEGFA in luteal pericytes. ${ }^{47}$

Increased preovulatory ovarian flow may also be attributed partially to increased nitric oxide production ${ }^{47}$ following the upregulation of eNOS and inducible NOS in the thecal vasculature. ${ }^{48}$ This may be due to upregulation of E2 as it is a more potent and rapid stimulator of eNOS than $\mathrm{LH}$ in endothelial cells. ${ }^{49}$ It is also speculated that LH surge may be inducing HIF1A expression directly.

The connective tissue growth factor (CTGF) is a paracrine regulator of cell proliferation and is especially active in remodeling of the extracellular matrix. Its expression is highest in the midantral stage granulosa cells, but declines in preovulatory follicles. Interestingly, though responsible for vascularity, it is downregulated during $\mathrm{FSH}$-induced granulosa cell maturation. ${ }^{50}$

A linear increase in the capillary cross-sectional area of the theca interna was observed after the LH surge in a spontaneous cycle and the increase in capillary area was attributed to vasodilatation rather than increase in the number of vessels..$^{51}$ The LH is responsible for the influx of blood in the ovary and neoangiogenesis that is essential for the follicular and in turn ovum oxygenation; therefore, in the preovulatory phase rising LH level reflects as rising PSV. Increase in PSV starts 29 hours before ovulation and continues for at least 72 hours after ovulation. ${ }^{52,53}$ Increased blood flow thus results in more oxygen supply to the tissues. 


\section{Follicular Rupture}

The LH surge upregulates numerous genes (e.g., cyclo-oxygenase and progesterone receptor) that induce a series of cellular and biochemical processes that culminate in ovulation. ${ }^{54}$ After the ovulation occurs, there is neovascularization that invades into the theca layer of the ruptured follicle. This flow typically is a lowresistance high velocity flow. The RI of the corpus luteum is as low as $0.39-0.47$ in the early luteal phase (4-5 days), then starts increasing, and in normal luteal phase it remains in the range of $0.45-0.53$ till the mid-luteal phase. ${ }^{54}$ When collapse of the follicle occurs, the thecal layer with blood vessels get placed within the folds of the granulosa compartment.

Follicular rupture leads to breach in the basement membrane, which facilitates newly formed vessels to cross the basement membrane to grow between the basement membrane and the theca cell layer to sustain the corpus luteum. ${ }^{55}$ Loss of integrity of the basement membrane, accompanied by extensive tissue remodeling, leads to commencement of invasion of the differentiating granulosa lutein cell in the region supported by new blood vessel development from the preexisting thecal vasculature. Variable amounts of blood and plasma extravasate into the follicular cavity to form a fibrin-rich clot. ${ }^{56}$

To maintain the adequate tropic supply of the germinal structure, the VEGF isoform with high molecular weight is produced and this protein has a different solubility. The unchanged follicular fluid and granulosa content maintains the inner vascular network. The outer network is significantly decreased by absence of large blood vessels presenting in the inner theca folds. This results in the physiological transition from the periovulatory follicle to the corpus luteal structure.

\section{Luteal Phase and Angiogenic Factors}

The corpus luteum is a site of intense angiogenesis. All differentiated lutein cells are in relation with the endothelial cells and are one of the most vascularized tissues in the body. ${ }^{57-59}$ In an active early corpus luteum, more than $50 \%$ cells are endothelial cells and more than $80 \%$ dividing cells in the early corpus luteum are endothelial cells. It is the proliferating volume of lutein cells that evidently affects vascularity by spreading the endothelial cells, thus reducing the population of endothelial cells per unit area of tissue. ${ }^{60}$ Endothelial cell proliferation is soon followed by pericyte proliferation and progresses with advancing luteal phase. ${ }^{61}$ Its stability is established by pericyte proliferation and recruitment, which is continued under the influence of human chorionic gonadotrophin (hCG) with Ang-1. ${ }^{62} \mathrm{hCG}$ is a more potent stimulator of HIF1A than hypoxia in luteinizing cells. ${ }^{63}$ When this was taken into account, hCG-induced rescue of the corpus luteum was found to be associated with a significant increase in endothelial cell content of the human corpus luteum. ${ }^{64}$

Luteal steroidogenic cells produce chemoattractants that stimulate endothelial cell migration toward themselves. Concentrations of estrogen metabolites with proangiogenic activity (16-ketoestradiol and 4-hydroxyestrone) are higher in early and midluteal phase corpus luteum. These and hCG increase VEGF production and angiogenic activity. Luteal angiogenesis is stimulated by hypoxia, which in turn activates synthesis of angiogenetic factors. ${ }^{65}$ The VEGF is a family of factors of which VEGF-A is the active member in the corpus luteum, produced from the luteinizing granulosa cells further stimulated by hCG ${ }^{63,66}$ The FGF2 has a critical role in endothelial cell proliferation and sprouting.
Luteal angiogenesis is regulated by a delicate balance between the stimulatory and inhibitory factors, of which post-transcriptional regulation by small noncoding microRNAs is also likely to play a central role in the regulation of luteal angiogenesis. ${ }^{67}$ The VEGF mRNA is detected in the lutein cells derived from granulosa cells as the corpus luteum is formed and VEGF mRNA continues to be expressed throughout the luteal phase and is responsible for survival of the endothelial cells. ${ }^{62,68}$

Luteinizing hormone (LH) regulates these factors as these are produced in lutein cells in response to LH stimulation. ${ }^{62,69,70}$ Rich vascularity of the corpus luteum is due to high VEGF expression. High VEGF expression is maintained in the mid-luteal phase to increase vascular permeability that results in enhancement of luteal function. ${ }^{18}$ The VEGF is chiefly responsible for endothelial cell proliferation acting through two tyrosine kinase receptors, VEGFR-1 (flt-1) and VEGFR-2 (KDR). ${ }^{70}$ Higher VEGF expression in the early luteal phase is essential for the development of a high-density capillary network in the corpus luteum. Contrary to the follicles, in the corpus luteum, VEGF expression is high in both granulosa and theca layers.

Proliferative cell nuclear antigen positivity is also increased in endothelial layers. Though this activity is decreased in midand late-luteal phase. Fibroblast growth factor 2 and VEGFA are primarily localized to these steroidogenic luteal cells, in collapsed follicles. ${ }^{8,71-73}$ Permeability of the endothelial cell membrane is due to fenestrations that facilitate exchange of fluid and small solutes between interstitial fluid and plasma associated with the corpus luteum. Depending on variations in the expression of the various angiogenic factors, the vascularity of the corpus luteum may change in various phases of the luteal phase.

Development of the corpus luteal vascularity and its regression also depends on ANPTs, Ang-1 and Ang-2. Ang-1 stimulates stabilization of blood vessels while Ang-2 causes destabilization. ${ }^{39}$ Ang-1 acts via the same receptor as a competitive antagonist and enhances the stability of the newly formed blood vessels by recruiting pericytes. ${ }^{39}$ Expression of Ang-2 is intense in a small number of endothelial cells and a few hormone-producing cells while Ang-1 expression is low and diffuse. ${ }^{66}$ Ang-2 aids the action of VEGF by reducing endothelial contact with the extracellular matrix and adjacent endothelial cell interactions through its tyrosine kinase receptor, Tie-2.

The connective tissue growth factor (CTGF) has also been proposed as a promoter of migration of endothelial cells in the corpus luteum. It is a cysteine-rich secretory protein, a member of cysteine-rich $61 /$ nephroblastoma-overexpressed family of genes. ${ }^{74,75}$

Insulin-like growth factor binding protein-3 is highly expressed in luteal endothelial cells and may be responsible for accessibility of IGF. ${ }^{76}$ The IGF system appears to have indirect effects on angiogenesis through stimulatory action for VEGF production in luteal cells, as well as through the stimulus of endothelial cell proliferation and differentiation. ${ }^{77}$

In pregnancy, the function and angiogenesis of the corpus luteum needs to be sustained and is believed that this is supported by hCG. But adding hCG has not shown increase in angiogenesis in humans. ${ }^{54}$ If the conception has occurred, this RI further falls to $0.41-0.49$ toward the end of the cycle, but if the conception has not occurred there is a fast decrease in the blood flow in the corpus luteum. ${ }^{78-80}$ This suggests that the vascular tree required for the corpus luteum of pregnancy is already established during the normal luteal phase. The expression of adrenomedullin, its receptor, 
and LH/hCG receptor may be important components in the process of development and differentiation of the corpus luteum. These levels are low in mature follicle and increase in the corpus luteum of the mid-luteal phase and are maintained during early pregnancy.

\section{Corpus Luteum Regression}

The corpus luteum is maintained till the mid-luteal phase. Theca and granulosa cells receive oxygen, nutrients, and hormone precursors to produce progesterone to support early pregnancy through the blood vessels. ${ }^{81}$ But with a nonconception cycle, luteal vasculature rapidly regresses to enable the next cycle of ovarian activity. Regression of the vascularity indicates the atresia of the follicles. ${ }^{9,82}$ The VEGF mRNA falls during regression of the corpus luteum, from mid-to late luteal phase ${ }^{62,71}$ and the Ang-2:Ang-1 ratio increases that destabilizes vessels in the $\mathrm{CL}$ and leads to vascular regression via apoptosis. ${ }^{40}$

The Northern blot analysis and semi-quantitative PCR in the human corpus luteum ${ }^{62,63}$ demonstrated expression of VEGFR-1 and VEGFR-2 mRNA at all stages of the luteal phase with a two- to threefold decline in the late luteal phase. The interclass correlation coefficient (ICC) localizes VEGFR-1 and VEGFR-2 to luteal endothelial cells, but also to hormone-producing cells. ${ }^{68,83}$ The molecular regulation of vascular regression in the corpus luteum in human being is not yet well understood. In human corpus luteum, major changes in gene expression of angiogenic factors or their receptors do not appear to precede vascular regression. RU486 blocks progesterone and decreases VEGF synthesis in theca layer, but not in granulosa cells or follicular fluid. ${ }^{83,84}$

Withdrawal of LH may disrupt VEGF, the action of other luteal factors, cell-cell interactions necessary for angiogenesis, and survival of hormone-producing cells. LH might also have some direct effects on angiogenesis. ${ }^{85}$ Fibroblast growth factor 2 production by human luteinizing granulosa cells in vitro remains unaffected by LH surge. ${ }^{30}$

If the patient does not conceive, there is complete regression of the microvascular tree and if the patient conceives the entire vasculature converts into a comparatively more permanent one. ${ }^{86}$ Decreased blood supply will surely lead to lutein cell death and corpus luteal regression.

Luteolysis is thought to be a result of programmed cell death of the hormone-producing cells associated with apoptosis due to ischemia and hypoxia associated with regression of the vascular network also. Apoptosis represents an initial step in structural luteolysis, after which most steroidogenic cells survive to undergo a process of gradual involution. ${ }^{87}$ Peak apoptosis of theca-lutein and granulosa-lutein cells in the corpus luteum in the human is found in the perimenstrual period. ${ }^{83}$

The corpus luteum of the late luteal phase has significantly higher levels of 2-methoxyestrone and 2-methoxyestradiol, with antiangiogenic activity. Thrombospondin 1 and 2 bind to their receptor CD36 and inhibit angiogenesis, inducing endothelial cell apoptosis. Its expression decreases during follicle maturation. Human chorionic gonadotrophin can modify the concentrations of both. ${ }^{62}$ Platelet factor- 4 inhibits angiogenesis and the inhibitory effects are due to the formation of complexes with FGF-2, inhibiting FGF-2 binding to its receptors. ${ }^{88}$

\section{Conclusion}

Follicular angiogenesis plays a major role in development and maturation of the follicle and activity of the corpus luteal. The angiogenesis, apart from hormones, is controlled by several factors and hormones with VEGF, Ang 1, Ang 2, FGF, etc. Folliclestimulating hormone and LH have a key role. Manipulation of these hormones and factors can be useful for correction of ovulation problems.

\section{References}

1. Martelli A, Palmerini MG, Russo V, et al. Blood vessel remodeling in pig ovarian follicles during the periovulatory period: an immunohistochemistry and SEM-corrosion casting study. Reprod Biol Endocrinol 2009;16(1):72-85. DOI: 10.1186/1477-7827-7-72.

2. Hafez S, Caceci T. Microvascular corrosion casting of the ovary in nonpregnant and pregnant does. FASEB J 2017;31:Ib28.

3. Berisha B, Schams D, Rodler D, et al. Angiogenesis in the ovary - the most important regulatory event for follicle and corpus luteum development and function in cow - an overview. Anat Histol Embryol 2016;45(2):124-130. DOI: 10.1111/ahe.12180.

4. Camussi G, Deregibus MC, Bruno S, et al. Exosomes/microvesicles as a mechanism of cell-to cell communication. Kidney Int 2010;78(9):838848. DOI: 10.1038/ki.2010.278.

5. Olfert IM, Baum O, Hellsten Y, et al. Advances and challenges in skeletal muscle angiogenesis. Am J Physiol Heart Circ Physiol 2016;310(3):326-336. DOI: 10.1152/ajpheart.00635.2015.

6. Hazzard TM, Stouffer RL. Angiogenesis in ovarian follicular and luteal development. Baillieres Best Pract Res Obstet Gynecol 2000;14(6):883-900.

7. Gougeon A. Dynamics of human follicular growth: morphologic, dynamic and functional aspects 2nd ed. The Ovary 2004.

8. WulffC, Wilson $\mathrm{H}$, Wiegand SJ, et al. Prevention of thecal angiogenesis, antral follicular growth, and ovulation in the primate by treatment with vascular endothelial growth factor trap R1R2. Endocrinology 2002;143(7):2797-2807. DOI: 10.1210/endo.143.7.8886.

9. Feng $Y$, Cui $P$, Lu X, et al. CLARITY reveals dynamics of ovarian follicular architecture and vasculature in three-dimensions. Sci Rep 2017;7(1):44810. DOI: 10.1038/srep44810.

10. Mattioli M, Barboni $B$, Turriani $M$, et al. Follicle activation involves vascular endothelial growth factor production and increased blood vessel extension. Biol Reprod 2001;65(4):1014-1019. DOI: 10.1095/ biolreprod65.4.1014.

11. Carmeliet $P$, Jair RK. Angiogenesis in cancer and other diseases. Nature 2000;407(6801):249-257. DOI: 10.1038/35025220.

12. Redmer DA, Reynolds LP. Angiogenesis in the ovary. Rev Reprod 1996;1(3):182-192. DOI: 10.1530/ror.0.0010182.

13. Zaidi J, Barber J, Kyei-mensah A, et al. Relationship of ovarian stromal blood flow at the baseline ultrasound scan to subsequent follicular response in an in vitro fertilization program. Obstet Gynecol 1996;88(5):779-784. DOI: 10.1016/0029-7844(96)00316-X.

14. Engmann L, Sladkevicius $P$, Agrawal $R$, et al. Value of ovarian stromal blood flow velocity measurement after pituitary suppression in the prediction of ovarian responsiveness and outcome of in vitro fertilization treatment. Fertil Steril 1999;71(1):22-29. DOI: 10.1016/ s0015-0282(98)00406-3.

15. Berardinelli P, Martelli A, Russo V, et al. Correlation between VEGF production and blood vessels density in steroidogenic activated pig antral follicles. Italian J Anat Embryol. 2002;107:115-126.

16. Young JM, McNeilly AS. Theca: the forgotten cell of the ovarian follicle. Reproduction 2010;140(4):489-504. DOI: 10.1530/REP-10-0094.

17. McFee RM, Rozell TG, Cupp AS. The balance of proangiogenic and antiangiogenic VEGFA isoforms regulate follicle development. Cell Tissue Res 2012;349(3):635-647. DOI: 10.1007/s00441-012-1330-y.

18. Acosta TJ, Hayashi KG, Ohtani M, et al. Local changes in blood flow within the preovulatory follicle wall and early corpus luteum in cows. Reproduction 2003;125(5):759-767. DOI: 10.1530/rep.0. 1250759.

19. Martelli A, Russo V, Mauro A, et al. Insights into ovarian follicle angiogenesis: morphological and chronological vascular remodeling from primordial to ovulating follicles SM. Vasc Med 2017;2(1): 1009. 
20. Kupesic S, Kurjak A. Uterine and ovarian perfusion during the periovulatory period assessed by transvaginal colour doppler. Fertil Steril 1993;3:439-443. DOI: 10.1016/s0015-0282(16)56157-3.

21. Grazul-Bilska AT, Navanukraw C, Johnson ML, et al. Vascularity and expression of angiogenic factors in bovine dominant follicles of the first follicular wave. J Anim Sci 2007;85(8):1914-1922. DOI: 10.2527/ jas.2007-0044.

22. Fraser HM, Lunn SF. Regulation and manipulation of angiogenesis in the primate corpus luteum CL. Reproduction 2001;121(3):355-362. DOI: $10.1530 /$ rep.0.1210355.

23. Martelli A, Berardinelli P, Russo V, et al. Spatiotemporal analysis of vascular endothelial growth factor expression and blood vessel remodelling in pig ovarian follicles during the periovulatory period. J Mol Endocrinol 2006;36(1):107-119. DOI: 10.1677/jme. 1.01921.

24. Tesone M, Stouffer RL, Borman SM, et al. Vascular endothelial growth factor (VEGF) production by the monkey corpus luteum during the menstrual cycle: isoform-selective mRNA expression in vivo and hypoxia-regulated protein secretion in vitro. Biol Reprod 2005;73(5):927-934. DOI: 10.1095/biolreprod.105.039875.

25. Ferrara N. Vascular endothelial growth factor: basic science and clinical progress. Endocr Rev 2004;25(4):581-611. DOI: 10.1210/ er.2003-2027.

26. Zeleznik AJ, Schuler HM, Reichert LJ. Gonadotropin-binding sites in the rhesus monkey ovary: role of the vasculature in the selective distribution of human chorionic gonadotropin to the preovulatory follicle. Endocinology 1981;109(2):356-362. DOI: 10.1210/endo-1092-356.

27. Furukawa $\mathrm{K}$, Fujiwara $\mathrm{H}$, Sato $\mathrm{Y}$, et al. Platelets are novel regulators of neovascularization and luteinization during human corpus luteum formation. Endocrinology 2007;148(7):3056-3064. DOI: 10.1210/ en.2006-1687.

28. Duggavathi R, Bartlewski $P$, Barrett $D$, et al. Use of high-resolution transrectal ultrasonography to assess changes in numbers of small ovarian antral follicles and their relationships to the emergence of follicular waves in cyclic ewes. Theriogenology 2003;60(3):495-510. DOI: 10.1016/s0093-691x(03)00041-4.

29. Robinson RS, Woad KJ, Hammond AJ, et al., 2009, unpublished observations.

30. Mauro A, Martelli A, Berardinelli P, et al. Effect of antiprogesterone RU486 on VEGF expression and blood vessel remodelling on ovarian follicles before ovulation. PLoS ONE 2014;9(4):1-13. DOI: 10.1371/ journal.pone.0095910.

31. Abe K, Minegishi T, Ibuki Y, et al. Expression of adrenomedullin in the human corpus luteum. Fertil Steril 2000;74(1):141-145. DOI: 10.1016/ s0015-0282(00)00585-9.

32. Kaczmarek MM, Schams D, Ziecik AJ. Role of vascular endothelial growth factor in ovarian physiology-an overview. Reprod Biol 2005;5(2):111-136.

33. Levin ER, Rosen GF, Cassidenti DL, et al. Role of vascular endothelial cell growth factor in ovarian hyperstimulation syndrome. J Clin Invest 1998;102(11):1978-1985. DOI: 10.1172/JCI4814.

34. Le Couter J, Lin R, Ferrara N. Endocrine gland-derived VEGF and the emerging hypothesis of organ-specific regulation of angiogenesis. Nat Med 2002;8(9):913-917. DOI: 10.1038/nm0902-913.

35. LeCouter J, Kowalski J, Foster J, et al. Identification of an angiogenic mitogen selective for endocrine gland endothelium. Nature 2001;412(6850):877-884. DOI: 10.1038/35091000.

36. Li M, Bullock CM, Knauer DJ, et al. Identification of two prokineticin CDNAs: recombinant proteins potently contract gastrointestinal smooth muscle. Mol Pharmacol 2001;59(4):692-698. DOI: 10.1124/ mol.59.4.692.

37. Lin DC, Bullock CM, Ehlert FJ, et al. Identification and molecular characterisation of two closely related $\mathrm{G}$ protein-coupled receptors activated by prokineticins/endocrine gland vascular endothelial growth factor. J Biol Chem 2001;277(22):19276-19280. DOI: 10.1074/ jbc.M202139200.
38. Lin R, Le Couter J, Kowalski J, et al. Characterization of EGVEGF signaling in adrenal cortex capillary endothelial cells. J Biol Chem 2002;277(10):8724-8729. DOI: 10.1074/jbc.M110594200.

39. Ferrara N, Frantz G, LeCouter J, et al. Differential expression of the angiogenic factor genes VEGF and EG-VEGF in normal and polycystic human ovaries. Am J Pathol 2003;162(6):1881-1893. DOI: 10.1016/ S0002-9440(10)64322-2.

40. Corner GWJ. The histological dating of the human corpus luteum of menstruation. Am J Anat 1956;9(3):377-401. DOI: 10.1002/ aja.1000980304.

41. Maisonpierre PC, Suri C, Jones PF, et al. Angiopoietin-2, a natural antagonist for Tie2 that disrupts in vivo angiogenesis. Science 1997;277(5322):55-60. DOI: 10.1126/science.277.5322.55.

42. Duncan WC, van den Driesche S, Fraser HM. Inhibition of vascular endothelial growth factor in the primate ovary up-regulates hypoxia-inducible factor-1 alpha in the follicle and corpus luteum. Endocrinology 2008;14(9):3313-3320. DOI: 10.1210/en.2007-1649.

43. Abramovich D, Parborel F, Tesone M. Effect of a vascular endothelial growth factor (VEGF) inhibitory treatment on the folliculogenesis and ovarian apoptosis in gonadotropin-treated prepubertal rats. Biol Reprod 2006;75(3):434-441. DOI: 10.1095/biolreprod.106. 051052.

44. Nilsson EE, Detzel C, Skinner MK. Platelet-derived growth factor modulates the primordial to primary follicle transition. Reproduction 2006;13(1):1007-1015. DOI: 10.1530/rep.1.00978.

45. van Wezell L, Umapathysivam K, Tilley WD, et al. Immunohistochemical localization of basic fibroblast growth factor in bovine ovarian follicles. Mol Cell Endocrinol 1995;11(5):133-140. DOI: 10.1016/03037207(95)03678-4.

46. Augustin HG. Development of the vascular system of the corpus luteum. In: Risau W. Morphogenesis of Endothelium. U.K: Harwood Academic Publishers; 2000. pp. 237-254.

47. Torres-Ortiz MC, Gutiérrez-Ospina G, Gómez-Chavarín M, et al. The presence of VEGF and Notch2 during preantral-antral follicular transition in infantile rats: anatomical evidence and its implications. Gen Comp Endocrinol 2017;249:82-92. DOI: 10.1016/ j.ygcen.2017.05.006.

48. Grazul-Bilska A, Navanukraw C, Johnson M, et al. Expression of endothelial nitric oxide synthase in the ovine ovary throughout the estrous cycle. Reproduction 2006;13(2):579-587. DOI: 10.1530/REP06-0009.

49. Beckman JD, Grazul-Bilska AT, Johnson ML, et al. Isolation and characterization of ovine luteal pericytes and effects of nitric oxide on pericyte expression of angiogenic factors. Endocrine 2006;29(3): 467-476. DOI: 10.1385/endo:29:3:467.

50. Mitsube K, Zackrisson U, Brannstrom M. Nitric oxide regulates ovarian blood flow in the rat during the periovulatory period. Hum Reprod 2002;17(10):2509-2516. DOI: 10.1093/humrep/17.10.2509.

51. Kim KH, Moriarty K, Bender JR. Vascular cell signaling by membrane estrogen receptors. Steroids 2008;73(9-10):864-869. DOI: 10.1016/ j.steroids.2008.01.008.

52. Harlow CR, Hillier SG. Connective tissue growth factor in the ovarian paracrine system. Mol Cell Endocrinol 2002;187(1-2):23-27. DOI: 10.1016/s0303-7207(01)00702-x.

53. Cavander JL, Murdoch WJ. Morphological studies of the microcirculatory system of periovulatory ovine follicles. Biol Reprod 1990;42(1):139-149. DOI: 10.1095/biolreprod42.1.139.

54. Campbell S, Bourne T, Waterstone J, et al. Transvaginal color blood flow imaging of the preovulatory follicle. Fertil Steril 1993;60(3): 433-438. DOI: 10.1016/S0015-0282(16)56156-1.

55. Reynolds LP, Redmer DA. Growth and development of the corpus luteum. J Reprod Fertil Suppl 1999;54:181-191.

56. Kurjak A, Kupesic-Urek S. Infertility. In: Kurjak A. Transvaginal color Doppler. Carnforth, UK: Parthenon Publishing; 1991. pp. 33-38.

57. Tamanini C, De Ambrogi M. Angiogenesis in developing follicle and corpus luteum. Reprod Domest Anim 2004;39(4):206-216. DOI: 10.1111/j.1439-0531.2004.00505.x. 
58. Kamat BR, Brown LF, Manseau EJ, et al. Expression of vascular permeability factor/vascular endothelial growth factor by human granulosa and theca lutein cells. Am J Pathol 1995;146(1):157-165.

59. Rodger FE, Young FM, Fraser HM, et al. Endothelial cell proliferation follows the mid-cycle luteinizing hormone surge, but not human chorionic gonadotrophin rescue, in the human corpus luteum. Hum Reprod 1997;12(8):1723-1729. DOI: 10.1093/humrep/12.8.1723.

60. Gaytán F, Morales C, García-Pardo L, et al. Macrophages, cell proliferation, and cell death in the human menstrual corpus luteum. Biol Reprod 1998;59(2):417-425. DOI: 10.1095/biolreprod59. 2.417.

61. Shweiki D, Itin A, Neufeld G, et al. Patterns of vascular endothelial growth factor (VEGF) and VEGF receptors in mice suggest a role in hormonally regulated angiogenesis. J Clin Invest 1993;91(5): 2235-2243. DOI: 10.1172/JCI116450.

62. Gaytán F, Morales C, García-Pardo L, et al. A quantitative study of changes in the human corpus luteum microvasulature during the menstrual cycle. Biol Reprod 1999;60(4):914-919. DOI: 10.1095/ biolreprod60.4.914.

63. Wulff C, Dickson SE, Duncan WC, et al. Angiogenesis in the human corpus luteum: simulated early pregnancy by HCG treatment is associated with both angiogenesis and vessel stabilization. Hum Reprod 2001;16(12):2515-2524. DOI: 10.1093/humrep/16.12.2515.

64. Sugino N, Kashida S, Takiguchi S, et al. Expression of vascular endothelial growth factor and its receptors in the human corpus luteum during the menstrual cycle and in early pregnancy. J Clin Endocrinol Metab 2000;85(10):3919-3924. DOI: 10.1210/ jcem.85.10.6888.

65. van den Driesche S, Myers M, Gay E, et al. HCG up-regulates hypoxia inducible factor- 1 alpha in luteinized granulosa cells: Implications for the hormonal regulation of vascular endothelial growth factor $A$ in the human corpus luteum. Mol Hum Reprod 2008;14(8):455-464. DOI: 10.1093/molehr/gan040.

66. Ferrara N, Davis-Smyth T. The biology of vascular endothelial growth factor. Endocr Rev 1997;18(1):4-25. DOI: 10.1210/edrv.18.1.0287.

67. Neulen J, Raczek S, Pogorzelski M, et al. Secretion of vascular endothelial growth factor/vascular permeability factor from human luteinized granulosa cells is human chorionic gonadotrophin dependent. Molec Hum Reprod 1998;4(3):203-206. DOI: 10.1093/ molehr/4.3.203.

68. Wulff $C$, Wilson $H$, Largue $P$, et al. Angiogenesis in the human corpus luteum: localization and changes in angiopoietins, tie-2 and vascular endothelial growth factor messenger ribonucleic acid. J Clin Endocrinol Metab 2000;85(11):4302-4309. DOI: 10.1210/ jcem.85.11.6942.

69. Woad JK, Robinson RS. Luteal angiogenesis and its control. Theriogenology 2016;86(1):221-228. DOI: 10.1016/j.theriogenology. 2016.04.035.

70. Otani N, Sawako M, Yamoto M, et al. The vascular endothelial growth factor/fms-like tyrosine kinase system in human ovary during the menstrual cycle and early pregnancy. J Clin Endocrinol Metab 1999;84(10):3845-3851. DOI: 10.1210/jcem.84.10.6025.

71. Dickson SE, Fraser HM. Inhibition of early luteal angiogenesis by gonadotropin-releasing hormone antagonist treatment in the primate. J Clin Endocrinol Metab 2000;85(6):2339-2344. DOI: 10.1210/ jcem.85.6.6621.

72. Laitinen $M$, Ristimäki $A$, Honkasalo $M$, et al. Differential hormonal regulation of vascular endothelial growth factors VEGF, VEGF-B, and VEGF-C messenger ribonucleic acid levels in cultured human granulosa-luteal cells. Endocrinology 1997;138(11):4748-4756. DOI: 10.1210/endo.138.11.5500.

73. Berisha B, Schams D, Kosmann M, et al. Expression and tissue concentration of vascular endothelial growth factor, its receptors, and localization in the bovine corpus luteum during estrous cycle and pregnancy. Biol Reprod 2000;63(4):1106-1114. DOI: 10.1095/ biolreprod63.4.1106.

74. Kaczmarek MM, Kowalczyk AE, Waclawik A, et al. Expression of vascular endothelial growth factor and its receptors in the porcine corpus luteum during the estrous cycle and early pregnancy. Mol Reprod Dev 2007;74(6):730-739. DOI: 10.1002/mrd.20638.

75. Robinson RS, Nicklin LT, Hammond AJ, et al. Fibroblast growth factor 2 is more dynamic than vascular endothelial growth factor A during the follicle-luteal transition in the cow. Biol Reprod 2007;7(1):728-736. DOI: 10.1095/biolreprod.106.055434.

76. Wandji SA, Gadsby JE, Barber JA, et al. Messenger ribonucleic acids for MAC25 and connective tissue growth factor (CTGF) are inversely regulated during folliculogenesis and early luteogenesis. Endocinology 2000;141(7):2648-2657. DOI: 10.1210/endo.141.7.7576.

77. Perbal B. CCN proteins: multifunctional signalling regulators. Lancet 2004;363(9402):62-64. DOI: 10.1016/S0140-6736(03)15172-0.

78. Fraser HM, Lunn SF, Kim H, et al. Insulin-like growth factor binding protein-3 (IGFBP-3) mRNA in the endothelial cells of the primate corpus luteum. Hum Reprod 1998;13(8):2180-2185. DOI: 10.1093/ humrep/13.8.2180.

79. Schams D, Kosmann M, Berisha B, et al. Stimulatory and synergistic effects of luteinising hormone and insulin-like growth factor 1 on the secretion of vascular endothelial growth factor and progesterone of cultured bovine granulosa cells. Exp Clin Endocrinol Diabetes 2001;109(3):155-162. DOI: 10.1055/s-2001-14839.

80. Kupesic $S$, Kurjak $A$. The assessment of normal and abnormal luteal function by transvaginal colour doppler sonography. Eur J Obstet Gynecol 1997;72(1):83-87. DOI: 10.1016/s0301-2115(96)02666-8.

81. Salim A, Kurjak A, Zalud I. Ovarian luteal flow in normal and abnormal early pregnancies. J Matern Fetal Invest 1992;2:119.

82. Fraser HM, Wulff C. Angiogenesis in corpus luteum. Reprod Biol Endocrinol 2003;1(1):88. DOI: 10.1186/1477-7827-1-88.

83. Woodruff TK, Shea LD. A new hypothesis regarding ovarian follicle development: Ovarian rigidity as a regulator of selection and health. J Assist Reprod Genet 2011;28(1):3-6. DOI: 10.1007/s10815-0109478-4.

84. Endo T, Kitajima Y, Nishikawa A, et al. Cyclic changes in expression of mRNA of vascular endothelial growth factor, its receptors Flt-1 and KDR/Flk-1, and Ets-1 in human corpora lutea. Fertil Steril 2001;76(4):762-768. DOI: 10.1016/s0015-0282(01)02012-x.

85. Thompson JG, Brown HM, Kind KL, et al. The ovarian antral follicle: living on the edge of hypoxia or not? Biol Reprod 2015;92(6):153. DOI: 10.1095/biolreprod.115.128660.

86. Seli E, Zeyneloglu HB, Senturk LM, et al. Basic fibroblast growth factor: peritoneal and follicular fluid levels and its effect on early embryonic development. Fertil Steril 1998;69(6):1145-1148. DOI: 10.1016/s00150282(98)00074-0.

87. Phan B, Rakenius A, Pietrowski D, et al. hCG-dependent regulation of angiogenic factors in human granulosa lutein cells. Mol Reprod Dev 2006;73(7):878-884. DOI: 10.1002/mrd.20465.

88. Morales C, Garcia-Pardo L, Reymundo C, et al. Different patterns of structural luteolysis in the human corpus luteum of menstruation. Hum Reprod 2000;15(10):2119-2128. DOI: 10.1093/humrep/ 15.10.2119. 